\title{
Distribution of red king crabs and Tanner crabs in the summer by habitat and depth in an Alaskan fjord
}

\author{
Shijie Zhou ${ }^{1}$ and Thomas C. Shirley \\ Juneau Center, School of Fisheries and Ocean Sciences \\ University of Alaska Fairbanks \\ 11120 Glacier Highway \\ Juneau, AK 99801, USA
}

\begin{abstract}
A manned submersible was used in a fjord in southeastern Alaska to study the distributional patterns of the red king crab (Paralithodes camtschaticus) and the Tanner crab (Chionoecetes bairdi) in summer. The cove was divided into three zones: inner, middle, and outer. Six types of habitats, including sand-mud, rock, shell, debris, rock wall, and algae, were identified from video tapes. A relatively flat sand-mud habitat located at the center of the cove occupied $60 \%$ of the sea bottom. This large habitat was bordered by steep rocky walls on both sides in most parts of the fjord except in the inner zone. The density of red king crab decreased from the inner zone to the outer zone, while the density of the Tanner crab was more uniform throughout the cove. Highest crab density was found in the sand-mud habitat with an overall density of $51 \mathrm{crabs} \mathrm{ha}^{-1}$ for the red king crab and $41 \mathrm{crabs} \mathrm{ha}^{-1}$ for the Tanner crab. No crabs were found in rock wall and algae habitats. Both crab species displayed a dome-shaped distribution with depth with maximum density at intermediate depths. Red king crabs had a maximum density ( $\left.86 \mathrm{crabs} \mathrm{ha}^{-1}\right)$ at $70-80 \mathrm{~m}$ while the maximum density of Tanner crabs (105 crabs ha ${ }^{-1}$ ) was at 140-150 m of depth. Dense aggregations of juvenile red king crabs were observed in the inner cover, but no aggregations of mature red king and Tanner crabs were observed.
\end{abstract}

Key words: distribution, red king crabs, Paralithodes camstchasticus, Tanner crabs, Chionoecetes bairdi, Alaska.

\section{Distribución de la centolla y del cangrejo Tanner en verano, de acuerdo al hábitat y a la profundidad, en un fiordo de Alaska}

RESUMEN. Se utiliza un sumergible tripulado para estudiar los patrones de distribución de la centolla (Paralithodes camtschaticus) y del cangrejo Tanner (Chionoecetes bairdi), en un fiordo del sureste de Alaska durante el período de verano. El área de estudio fue dividida en tres zonas: interior, media, y exterior. Seis tipos de habitat, incluyendo fangoarena, roca, conchas, cascajo, pared rocosa y algas, fueron identificadas a través de grabaciones realizadas en cintas de video. Un habitat fango-arenoso relativamente plano, ubicado en el centro de la ensenada, ocupa el $60 \%$ del fondo del mar. Este gran habitat estaba bordeado por paredes rocosas abruptas a ambos lados en la mayor parte del fiordo, excepto en la zona más al interior. La densidad de la centolla disminuye desde la zona interna hacia la zona exterior, en tanto que la densidad del cangrejo Tanner se presentó uniforme en toda la ensenada. La más alta densidad se encontró en el habitat fango-arenoso, con un total de 51 individuos ha ${ }^{-1}$ para la centolla y 41 individuos ha ${ }^{-1}$ para el cangrejo. Ni en las paredes rocosas ni en las algas se encontraron cangrejos. Ambas especies mostraron una distribución en forma de domo respecto a la profundidad, con densidades máximas en profundidades intermedias. La centolla presenta densidad máxima (86 individuos ha ${ }^{-1}$ ) en 70-80 m mientras que el cangrejo Tanner (105 individuos ha- ${ }^{-1}$ ) a 140-150 m. Densas agregaciones de juveniles de centolla fueron observadas en la zona más interna de la ensenada, pero no se observaron allí agregaciones de individuos maduros de ninguna de estas especies.

Palabras claves: distribución, centolla, Paralithodes camstchasticus, cangrejo Tanner, Chionoecetes bairdi, Alaska.

\footnotetext{
${ }^{1}$ Corresponding author e-mail: shijieZ@ fishgame.state.ak.us Current address: Alaska Department of Fish and Game P.O. Box 25526, Juneau, AK 99802,USA
} 


\section{INTRODUCTION}

The red king crab (Paralithodes camtschaticus) and the Tanner crab (Chionoecetes bairdi) are the two most commercially important crab species in Alaska. Limited information on the distribution of mature red king and Tanner crabs by habitat is available. Surveys using trawls and crab pots indicate that mature crabs of the two species have overlapping ranges but are at least partially allopatric in their bathymetric and substrate distribution (Bright, 1967; Otto et al., 1982, 1984; Stevens et al., 1992, 1995).

The habitat of king crab varies with age and annual migratory movements (Bright, 1967). Wallace et al. (1949) reported that red king crabs were caught by tangle nets and trawls on nearly every type of bottom except where it was extremely rocky. There are four kinds of substrate in Kachemak Bay, Cook Inlet: muddy, muddy with scattered rock, rocky, and sandy. Of these four, adult king and Tanner crabs were most frequently collected in the muddy areas, and the muddy areas with scattered rock were only slightly less populated, while few crabs were found in rocky or sandy areas (Bright, 1967). Spawning red king crabs have been observed on kelp-covered reefs by SCUBA divers during late winter and spring (Powell and Nickerson, 1965), and Tanner crabs have been observed on mud bottom during the spring reproductive (mating) season (Stevens et al., 1994). There are no direct observations of habitat selection by mature red king and Tanner crabs during non-molting and mating seasons.

Remote sampling methods (crab pots and trawls) employed by commercial fishing and research surveys are habitat-restricted, and either attract crabs from unknown distances (pots) or sample expansive areas of the bottom (trawls). These techniques provide poor information on the microscale distribution of the crabs and their distribution by habitat and depth. For example, the aggregation or podding behavior was reported common in juvenile red king crabs and adult red king crabs and Tanner crabs during their mating season (Dew, 1990; Dew et al., 1992; Powell and Nickerson, 1965; Powell et al., 1973; Stevens et al., 1993, 1994; Stones et al., 1993). This behavior can only be discovered by direct observations either by a submersible, a remotely operated vehicle (ROV), or Scuba. Although Scuba provides detailed observations, the depth of observation is limited to aproximately $30 \mathrm{~m}$ or less. There are also no reports of direct observations on the distributional pattern of red king crabs or Tanner crabs during the nonmating season.

Manned submersibles are a relatively new technique for underwater surveys but have an increasing use in the study of benthic invertebrates and demersal fish on a variety of substrata (Krieger, 1992; O'Connel and Carlile, 1993; Pearcy et al., 1989; Starr et al., 1996; Stein et al., 1992; Stevens et al., 1994; Tyler and Zibrowius, 1991). In this study we employed the Delta research submersible to investigate the distribution of red king crabs and Tanner crabs by habitat and depth in a southeastern Alaskan fjord, and to compare the dispersion patterns of the two species during the summer season.

\section{METHODS}

The study was conducted from June 18-22, 1991, at Barlow Cove (58 $\left.22^{\prime} \mathrm{N}, 134^{\circ} 53^{\prime} \mathrm{W}\right)$, southeastern Alaska, approximately $50 \mathrm{~km}$ northwest of Juneau (Fig. 1). The Alaska Department of Fish and Game conducted a long-term, annual sampling effort with crab pots in the cove, which revealed that crab abundance in term of catch per unit effort (CPUE) decreased from the inner to the outer cove. Based on this CPUE information, we divided the study area into three zones: (1) inner, (2) middle, and (3) outer.

We used a two-man research submersible, the Delta, to conduct transects along the bottom of the cove. A total of 41 dives was completed during $5 \mathrm{~d}$. Transects were made during daylight, between 08:00 $\mathrm{AM}$ and 08:00 PM. All dives were initiated from a randomly selected location at the center of the cove to the shoreline, with the transect oriented perpendicular to the long axis of the cove. The support ship RV Pirateer tended the submersible and periodically established the location and transect direction of the submersible. During the transect, the pilot attempted to maintain the submersible at a constant speed and at a constant height above the bottom. Two video cameras, one in a fixed position located externally on the submersible and one handheld inside the submersible, continuously recorded the sea floor as the submersible moved along the transects. Additional still photographs were taken, and direct observations were recorded for the identification and analysis of animals and habitat types.

The time, temperature, depth, and the height of the depth transducer of the submersible off the sea floor were automatically recorded every 20 seconds. The length of transect (L) was recorded at the end of each transect. When the submersible was 
sitting horizontally on a level sea floor, the height of the depth transducer off the bottom is $0.93 \mathrm{~m}$, while the wider side (front side) of the view field of the video camera is $1.78 \mathrm{~m}$. The average field of view that the video camera covered was obtained by $\mathrm{W}=1.78 / 0.93 * \mathrm{H}$, where $\mathrm{H}$ is the average height of the transducer off the sea floor in a transect. The area of camera coverage in one transect is expressed by $\mathrm{A}=\mathrm{W} * \mathrm{~L}$ (L: transect length). The number of crabs was counted from the video tapes recorded by the fixed external video camera, and the density was obtained by dividing this number by the area $\mathrm{A}$. A $95 \%$ confidence interval $(95 \% \mathrm{CI})$ was calculated as the mean density $t a, v \cdot \mathrm{SE}$, where SE is the standard error of the mean density from different transects.

The substrata were divided into six types: sand-mud, rock, shell, debris, rock wall, and algae. Because it was difficult to identify sand, mud, or a mixture of both from video tapes, they were combined as one habitat type, sand-mud. Rocks were usually cobble-sized, but all large rocks are referred to as cobble. Debris consisted of decaying wood and algae. The algae substratum type differs from the

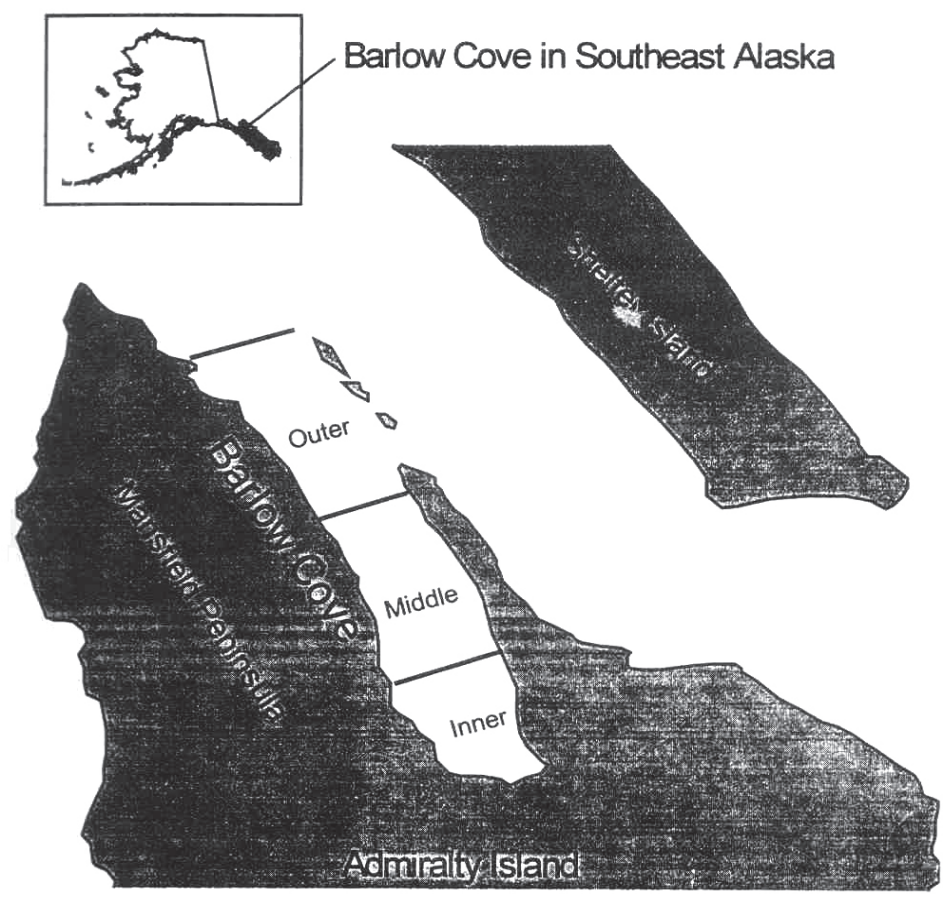

Figure 1. Map of Barlow Cove, showing the three zones.

Figura 1. Mapa de la Ensenada Barlow, mostrando las tres zonas de estudio. others in that it consisted of living marine plants, such as kelps. In the euphotic zone algae were dense in most parts of the cove so that the real substratum was not exposed to our view.

Depth was divided into strata of $10 \mathrm{~m}$ increments. The proportion of substratum and depth were based on the amount of time recorded within each $10 \mathrm{~m}$ depth increment or substratum type. The Kruskal-Wallis test was used to test for density differences among zones, and the G-test and Friedman Two-way ANOVA used to test for density differences among substrata.

\section{RESULTS}

\section{Topography of Barlow Cove}

Barlow Cove is a classic fjord, rectangular in shape, approximately $9.1 \mathrm{~km}$ long and $1.2 \mathrm{~km}$ in width, with steep walls and rocky intertidal areas. Semidiurnal tides in the area have amplitudes from 3.0 to $7.5 \mathrm{~m}$. The depth of the cove increased from the inner zone to the outer zone (Fig. 2). A deep, flat, sand-mud substratum along the central cove occupied most of the bottom. This central part of the cove was bordered by steep rock walls on both sides, except in the inner most part of the cove. Depths shallower than the rock wall were within the euphotic zone. The shallower depths typically had a sandmud substratum, dense algae and numerous sea anemones (Metridium sp.). Bivalve shells formed a substantial percentage of the substrate in some depth zones, usually at the upper and lower edges of the rock wall.

On average, the sand-mud substratum comprised $60.2 \%$ of the sea floor. Cobble, shell, debris, rock wall, and alga accounted for $15.9 \%, 11.6 \%$, $3.0 \%, \quad 5.7 \%$ and $3.6 \%$, respectively, of the sea floor (Fig. 3). Debris was mainly found in the inner cove on the central, flat bottom, while there was no rock wall in the inner zone. 
Direct observations of red king crabs and Tanner crabs

We observed that individuals of both the red king crab and Tanner crab did not aggregate, except

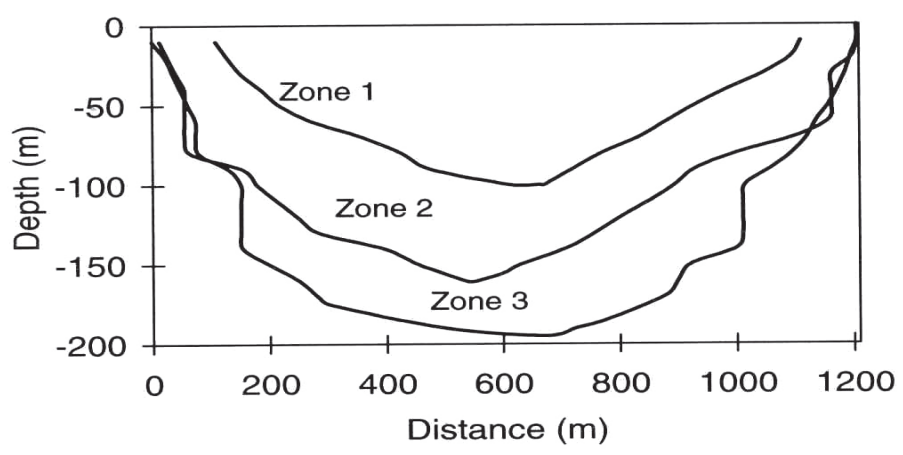

Figure 2. Vertical profile of depth distribution in the three zones in Barlow Cove.

Figura 2. Perfil vertical de distribución en profundidad en las tres zonas de la Ensenada Barlow.

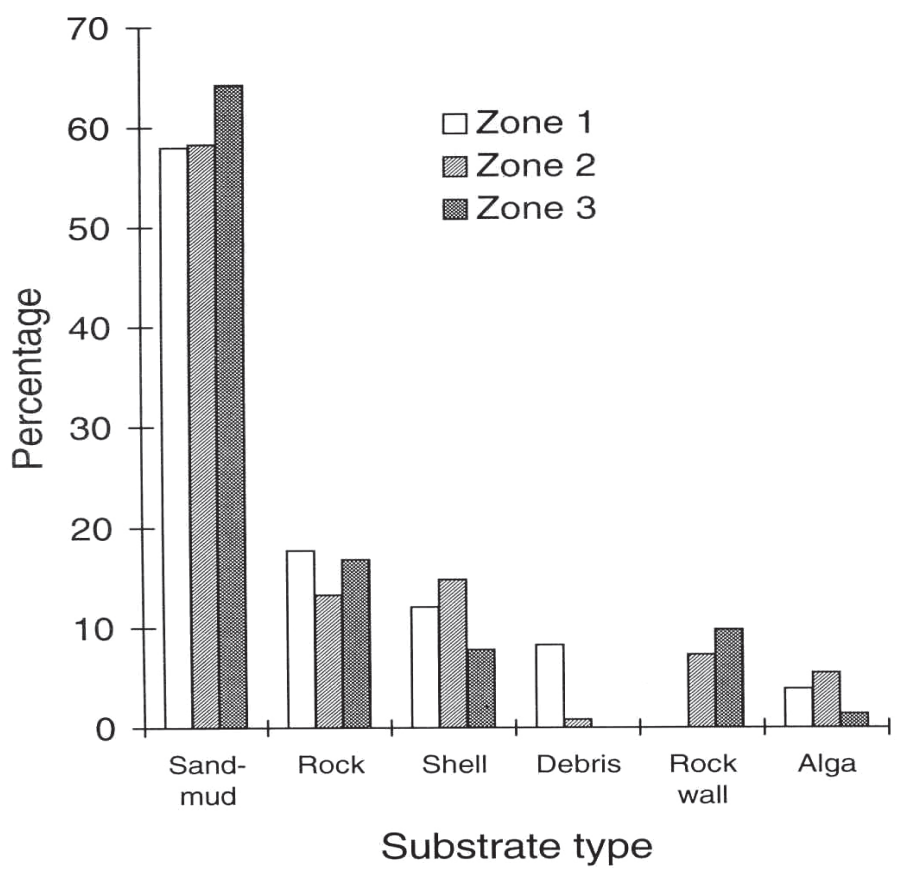

Figura 3. Composition of substratum type in the three zones.

Figura 3. Composición del tipo de sustrato en las tres zonas. juvenile red king crabs with carapace length less than $80 \mathrm{~mm}$. In most cases, red king crabs were foraging individually, separated more than 10 meters apart from other conspecifics. Red king crabs were observed feeding on debris, algae, and carcasses of fish several times. The submersible appeared to cause no obvious disturbance to the behavior of the crab when one meter or more away from the crab. Tanner crabs were frequently observed partially buried in the mud, with only the chelipeds and front carapace visible for some buried crabs. In two dives in the evening (around 8:00 PM) in the inner zone, a large number (estimated to be at least several thousands) of juvenile red king crabs were observed in pods. These crabs were approximately 50 to 70 $\mathrm{mm}$ in carapace length, and may be three to four years of age (McCaughran and Powell, 1977). They physically contacted each other, and were stacked up to several layers deep. Their quick moving and crawling on the top of other crabs indicated that the crabs were separating for foraging at night (Dew, 1990). On several other occasions during daytime in the inner zone, red king crabs of similar size as the podding crabs were observed but they were not so highly aggregated. Several crabs were close to each other but were not in physical contact with each other. From the inner cove to the outer cove, the size of red king crabs tended to increase. More large crabs with carapace length greater than $120 \mathrm{~mm}$ were observed in Zone 3.

Crabs density in the three zones

Out of 41 dives made with the Delta submersible, only 29 dives had useable data from the exterior fixed video camera. Out of these 29 dives with complete data, 17 were conducted in Zone 1, 9 in Zone 2, and 3 in Zone 3. We conducted transects over a total of $11,735 \mathrm{~m}$, 
covering 28,680 $\mathrm{m}^{2}$ of sea floor. A total of $149 \mathrm{red}$ king crabs and 83 Tanner crabs were observed within this area. All red king crabs observed from the fixed video camera were relatively large crabs, with carapace lengths greater than $100 \mathrm{~mm}$. We assumed that they were sexually mature or nearly mature (Paul, 1992). The density of red king crabs varied from 0 to 487 ha $^{-1}$, with an average of 52 crabs ha-1. The density of Tanner crabs varied from 0 to $152 \mathrm{ha}^{-1}$ with an average of $35 \mathrm{crabs} \mathrm{ha}^{-1}$ (Table $1)$.

Red king crabs had higher densities in the inner cove (Zone 1). The density of red king crabs differed significantly between zones (Kruskal-Wallis oneway ANOVA, $\mathrm{p}=0.029, \mathrm{df}=2$ ). However, significant differences only existed between Zones 1 and 3 by post hoc comparison (Conover, 1980). The density of Tanner crabs was similar among the three zones (Kruskal-Wallis one-way ANOVA, p=0.328, df=2). Red king crabs had a significantly higher density than Tanner crabs in the inner cove (Kruskal-Wallis test, $\mathrm{p}=0.046$ ), but no significant difference between the two species were found in Zone 2 and Zone 3 (Kruskal-Wallis test, $\mathrm{p}=0.227$ for Zone 2, and $\mathrm{p}=0.268$ for Zone 3).

\section{Crabs distribution by habitat}

The highest crab density was found on sand-mud habitat for both red king crabs and Tanner crabs, while neither was observed on rock walls or algae habitat. The data for the algae habitat may be biased because the substratum was not exposed to our view in most of the algae-covered area. A high density of red king crab was also present on debris. The null hypothesis of no differences in density among the substrata was rejected even if the rock wall and algae habitat, where no crabs were observed, were excluded (G-test, $\mathrm{p}<0.05, \mathrm{df}=3$, for both red king crab and the Tanner crab). Red king crabs had a higher density than Tanner crabs on the four habitats (Friedman two-way ANOVA, p<0.05, Fig. 4).

Table 1. Mean density (number of crabs per ha) of red king crab and Tanner crab in the three zones

Tabla 1. Densidad media (número de cangrejos por ha) de centolla y cangrejo Tanner en las tres zonas

\begin{tabular}{|lcccc|}
\hline \multicolumn{2}{|c}{ Red king crab density } & \multicolumn{3}{c|}{ Tanner crab density } \\
\hline Zone & $\mathbf{N}^{\mathbf{0}} \mathbf{h a}^{\mathbf{- 1}}$ & $\mathbf{9 5 \%} \mathbf{C I}$ & $\mathbf{N}^{\mathbf{0}} \mathbf{h a}^{\mathbf{- 1}}$ & $\mathbf{9 5 \%} \mathbf{C I}$ \\
\hline 1 & 73 & 25 & 39 & 29 \\
2 & 25 & 10 & 34 & 22 \\
3 & 4 & 7 & 18 & 36 \\
Total & 52 & 21 & 35 & 18 \\
\hline
\end{tabular}

\section{Crabs distribution by depth}

Red king crabs were observed from in the shallowest and deepest depths in transects in the cove, $10 \mathrm{~m}$ to $200 \mathrm{~m}$; Tanner crabs were found from $20 \mathrm{~m}$ to 200 $\mathrm{m}$. The bottom water temperature was fairly constant during the survey. It varied between 4.0 and $5.0^{\circ} \mathrm{C}$ at the depth where crabs were observed. Both red king crabs and Tanner crabs were not evenly distributed over depth (Fig. 5). The densities of both crab species increased with increasing depth to a maximum and then decreased at greater depths. For red king crabs the maximum density was at approximately $70-80 \mathrm{~m}$ where 23 red king crabs were observed in $2686 \mathrm{~m}^{2}$ (=86 crabs ha-1, combined from all transects). Tanner crabs seemed to occur deeper than red king crabs. The highest density of Tanner crabs was at 140-150 $\mathrm{m}$ where 9 crabs were observed in $858 \mathrm{~m}^{2}\left(=105 \mathrm{crabs} \mathrm{ha}^{-1}\right.$, combined from all transects).

\section{DISCUSSION}

Red king crabs and Tanner crabs have been reported to have seasonal migration and distribution patterns (Bright, 1967; Stone et al., 1992; Wallace et al., 1949). Our survey was conducted during June and may only present the distribution in that season. In Cook Inlet, Alaska, red king crabs have an annual two-cycle migratory pattern: a spawning migration from deep to shallow water during later winter and spring, and a feeding migration from the shallow to the deep beginning in June and July (Bright, 1967). Stone et al. (1992) reported that female red king crabs in Auke Bay, southeastern Alaska, migrate to deep water in spring after mating and egg extrusion, move into shallow water in winter, and back to intermediate depths to molt and mate between late March and May. Similar patterns have been reported in other studies (Hayess and Montgomery, 1962; Powell and Reynolds, 1965; Simpson and Shippen, 1968). Our survey should represent the distributional pattern of red king crabs during the summer.

Tanner crabs may not have pronounced migration as red king crabs do, but few studies have been conducted. In Cook Inlet some Tanner crabs move from deep to shallow areas in January and move back to deeper water in July, but many individuals remain at the same depth throughout the year (Bright, 1967). Donaldson (1980) reported that tagged male Tanner crabs do not move extensively form their release sites. Our survey depicts at least 
the distribution pattern of Tanner crabs during summer foraging season.

Habitat preference of red king crabs changes with ontogeny. In their earliest juvenile stages, red king crabs are found in shallow water on coarse substrates such as boulders, gravel, shell, and debris with attached epifauna (Fukuhara, 1985; 1988; Weber, 1967). With increasing size and age the crabs are found in deeper water (Dew et al., 1992). Our direct observations indicate a similar pattern, as more smaller red king crabs were observed in the shallow inner cove while more large crabs were observed in the deeper outer cove.

The high density of adult red king crabs in the sand-mud substratum indicates their habitat preference. This pattern has been mentioned in other studies with indirect observations (Bright, 1967; Feder and Jewett, 1987; Marukaw, 1933; Wallace, 1949). Red king crabs also had a high density in the debris substratum. Food availability on debris may attract

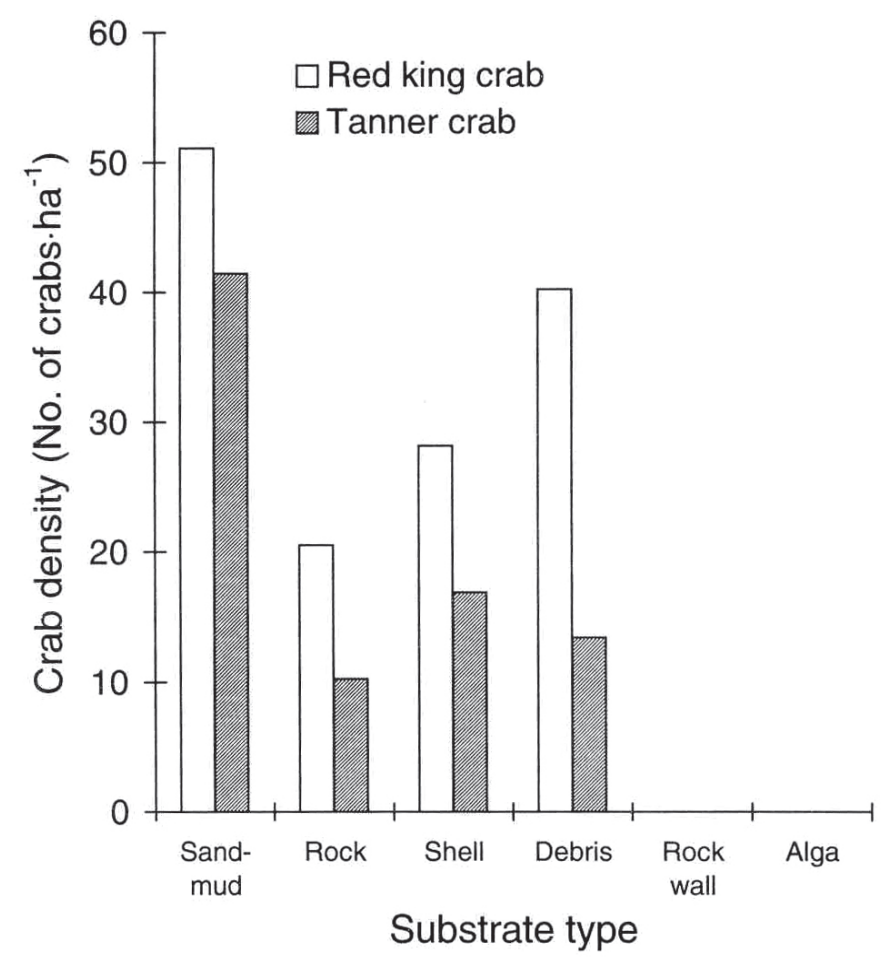

Figure 4. Density of the red king crab and the Tanner crab by types of substrata. Data are combined from all transects in the three zones. No crabs were found on rock wall or algae habitats.

Figura 4. Densidad de centolla y de cangrejo Tanner por tipo de sustrato. Los datos han sido combinados de todas las transectas realizadas en las tres zonas. No se encontraron cangrejos en la pared rocosa ni en el habitat de algas. the crabs, since red king crabs are scavengers. Jewett and Feder (1982) reported that sediments and plant materials had a high frequency of occurrence in the stomachs of the red king crab, $34.8 \%$ and $33.7 \%$, respectively.

The higher number of crabs on the sand-mud habitat was more evident in Tanner crabs. Because Tanner crabs have a behavior of burying in the sediment (Stevens et al. 1994a) and red king crabs do not, a sand-mud habitat may be more important for Tanner crabs. Unlike the red king crab, the Tanner crab did not have a high density in the debris habitat. Plant materials had a low frequency of occurrence $(5.7 \%)$ while sediments had a high frequency of occurrence $(56.4 \%)$ in stomach contents of Tanner crabs (Jewett and Feder, 1983). In the Bering Sea and Bristol Bay, red king crabs tend to occur closer to shore while the Tanner crab is found further offshore where the flat, mud habitat occupies most of the sea floor (Otto et al., 1982, 1984; Stevens et al., 1992, 1994b, 1996)

The depth distribution of red king crabs and Tanner crabs varies with the season and the locality. Red king crabs have been collected between subtidal zone to as deep as $384 \mathrm{~m}$ (Marukawa, 1933; Sloan, 1985); Tanner crabs have been found from the littoral zone to depths of $474 \mathrm{~m}$ (Bright, 1967). Within the same geographic area, Tanner crabs tend to occur deeper than red king crabs (Bright, 1967; Otto et al., 1982, 1984; Stevens et al., 1994). In our survey, although crabs were observed at nearly all depths in the transects, the domeshaped depth distribution implies that both red king crab and Tanner crab have depth preferences at least during the summer, and red king crabs occupy shallower depths than Tanner crabs. This depth preference may be associated with substrata preference. Sediment accumulates in deep water, and the proportion of muddy substratum increases with depth, as sand-mud substratum occupies a wider sea bottom from the inner zone to the outer zone in our survey.

Aggregation and podding behavior has been reported for both red king crabs and Tanner (Dew, 1990; Dew et al., 1992; Stevens et al., 1993, 1994a; Stone et al., 1993). Stone et al. 


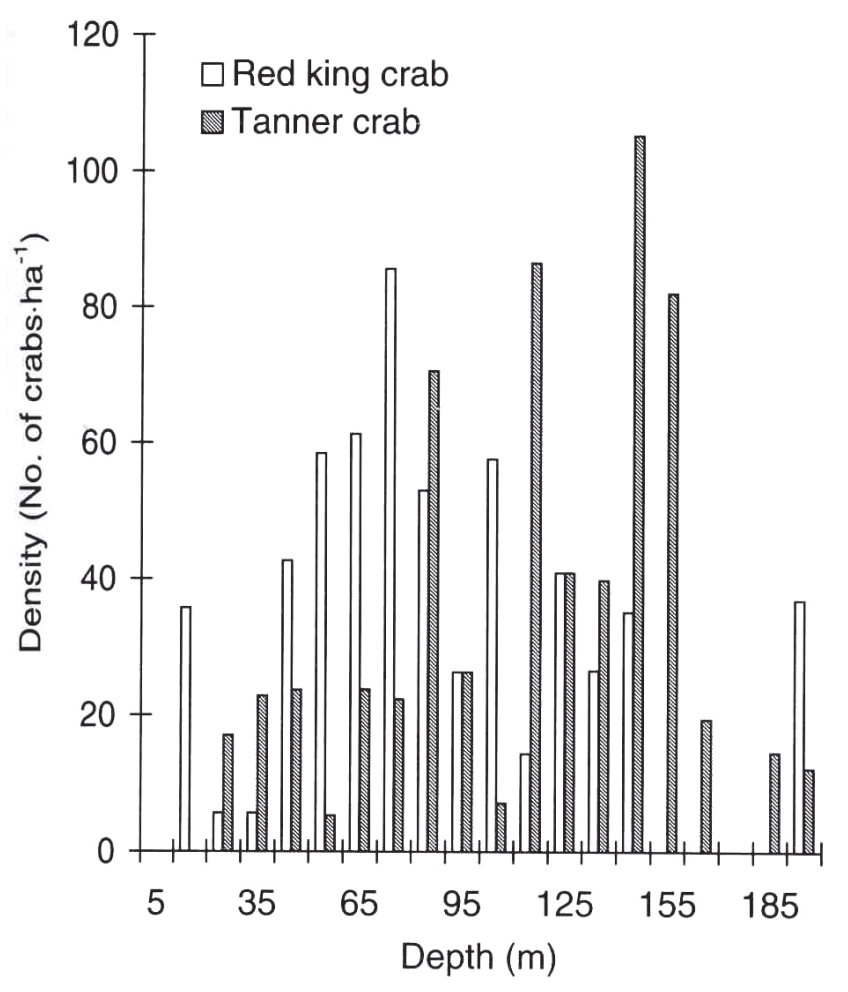

Figure 5. Density distribution of red king crabs and the Tanner crabs with depth. Data are combined from all transects in the three zones.

Figura 5. Distribución de densidad de centolla y cangrejo Tanner en profundidad. Datos combinados de todas las transectas realizadas en las tres zonas.

referred to structurally dense and socially organized groups of adults as aggregations, and referred to them as pods when the majority of individuals were in physical contact with each other and stacked atop one another. Podding is a typical behavior for juvenile red king crabs, and they form pods at daybreak and the pod breaks down at sunset (Dew, 1990). In our survey, red king crabs had their highest density in the inner cove, and there we also observed the pods of juvenile red king crabs in shallow water. However, we did not observe pods or aggregations of adult crabs. Crabs usually foraged individually except for juvenile crabs; only juvenile crabs occurred with more than two crabs in a single video field. There are probably two explanations why we did not encounter dense aggregations of mature crabs. First, we may have simply missed the aggregations; second, mature crabs might not aggregate during summer. Dense aggregations of red king crabs and Tanner crabs have only been reported during late winter and spring (Stevens $e t$ al., 1993, 1994a; Stone et al., 1993). This behavior is thought to be related to molting and mating (Powell and Nickerson, 1965; Stevens et al., 1994). During late June when we conducted our survey, reproductive activities of red king crabs and Tanner crabs may have completed (Powell and Nickerson, 1965; Powell et al. 1973; Shirley and Shirley, 1989; Shirley et al., 1990; Stevens et al., 1994; Tyler and Kruse, 1995), and adult crabs may disperse for foraging activities.

\section{ACKNOWLEDGMENT}

We especially thank Dr. C.E. O'Clair, NMFS, who contributed substantially to the field work and collection of data. We thank T. Koenemann, C. Botelho, K. Imamura and Dr. D. Woodby, all of Alaska Department of Fish and Game, who participated in other aspects of this study. We also thank the captains and crews of the research submersible Delta and the support RV Pirateer. D. Ackley assisted in preparation of a figure. This study was funded by the Office of Undersea Research, Submersible Science Program, NOAA.

\section{REFERENCES}

Bright, D. 1967. Life histories of the king crab, Paralithodes camtschatica, and the Tanner crab, Chionoecetes bairdi, in Cook Inlet, Alaska. Ph.D. Thesis, University of Southern California, Los Angels, California, 265 pp.

Conover,W.J.1980. Practical non parametric statistics. 2nd ed. John Wiley, NewYork, 494 pp.

Dew, C.B. 1990. Behavioral ecology of podding red king crab, Paralithodes camtschatica. Can. J. Fish. Aquat. Sci., 47: 1944-11958.

Dew, C.B., P.A. Cummiskey and J.E. Munk. 1992. The behavioral ecology and spatial distribution of red king crab and other target species: implications for sampling design and data treatment. Proc. Int. Crab Rehab. and Enhan. Symp., Alaska Dep. of Fish and Game and Kodiak College: 39-67. 
Donaldson, W.E. 1985. Movements of tagged males of Tanner crab, Chionoecetes bairdi Rathbun off Kodiak Island, Alaska. J. Shellfish Res., 3(2): 195201.

Feder, H.M. and S.C. Jewett. 1987. The subtidal benthos. In: D.W. Hood and S.T. Zimmerman (eds.), Gulf of Alaska: Physical Environment and Biological Resources. Government Printing Office, Washington, D.C. pp. 347-396.

Fukuhara, F.M. 1985. Biology and fishery of Southeastern Bering Sea red king crab (Paralithodes camtschatica, Tilesius). Northwest and Alaska Fisheries Center Processed Report, 85(11): $170 \mathrm{pp}$.

Haynes, M.L. and D.T. Montgomery. 1962. Movements of tagged king crabs form offshore releases, Shumagin Islands area, 1957-62. Manuscript Report MR 62-9. Bureau of Commercial Fisheries Biological Laboratory, Auke Bay, Alaska., 10 pp.

Jewett, S.C. and H.M. Feder. 1982. Food and feeding habits of the king crab Paralithodes camtschatica near Kodiak Island, Alaska. Mar. Biol., 66: 243250 .

Jewett, S.C. and H.M. Feder. 1983. Food of the Tanner crab Chionoecetes bairdi near Kodiak Island, Alaska. J. Crust. Biol., 3(2): 196-207.

Krieger, K. 1993. Distribution and abundance of rockfish determined from a submersible and by bottom trawling. US Fish. Bull., 91: 87-96.

Marukawa, H. 1933. Biological and fishery research on Japanese king crab Paralithodes camtschatica (Tilesius). J. Imp. Fish. Exp. Sta., 4: 152 pp.

McCaughran, D.A. and G.C. Powell. 1977. Growth model for Alaska King crab (Paralithodes camtschatica). J. Fish. Res. Board Can., 34: 989995.

O'Connell, V. and D.W. Carlile. 1993. Habitat-specific density of adult yelloweye rockfish Sebastes ruberrimus in the eastern Gulf of Alaska. US Fish. Bull., 91: 304-309.

Otto, R.S., R.A. MacIntosh, T.M. Armetta and W.S. Meyers. 1982. Report to industry on the 1982 Eastern Bering Sea crab survey. Northwest and Alaska Fisheries Center Processed Report, 82(13): $54 \mathrm{pp}$.

Otto, R.S., R.A. MacIntosh, K.L. Stahl-Johnson and S.J. Wilson. 1984. Report to industry on the 1982 Eastern Bering Sea crab survey. Northwest and Alaska Fisheries Center Processed Report, 84(17): $64 \mathrm{pp}$.
Paul, A.J. 1992. A review of size at maturity in male Tanner (Chionoecetes bairdi) and king (Paralithodes camtschaticus) crabs and the methods used to determine maturity. Amer. Zool., 32(3): 534-540.

Pearcy, W.G., D.L. Stein, M.A. Hixon, E.K. Pikitch, W.H. Barss and R.M. Starr. 1989. Submersible observations of deep-reef fishes of Heceta Bank, Oregon. US Fish. Bull., 87: 955-965.

Powell, G.C. and R.B. Nickerson. 1965. Reproduction of king crabs, Paralithodes camtschaticus (Tilesius). J. Fish. Res. Board Can., 22(1): 101111.

Powell, G.C. and R.E. Reynolds. 1965. Movements of tagged king crabs Paralithodes camtschatica (Tilesius) in the Kodiak Island--Lower Cook Inlet region of Alaska, 1954-63. Alaska Department of Fishand Game, Informational Leaflet, 55: 1-10.

Powell, G.C., B. Shafford and M Jones. 1973. Reproductive biology of young adult king crabs Paralithodes camtschatica (Tilesius) at Kodiak, Alaska. Proc. Natl. Shellfish. Assoc., 63: 77-87.

Shirley, S.M. and T.C. Shirley. 1989. Interannual variability in density, timing and survival of Alaska red king crab Paralithodes camtschatica larvae. Mar. Ecol. Prog. Ser., 54: 51-59.

Shirley, T.C., S.M. Shirley and S. Kon. 1990. Incubation period, molting and growth of female red king crabs: effects of temperature. In: Proc. Int. Symp. King and Tanner crabs, Nov. 1989, Anchorage, Alaska, 51-63.

Simpson, R.R. and H.H. Shippen. 1968. Movement and recovery of tagged king crabs in the eastern Bering Sea, 1956-1963. Int. North Pac. Fish. Comm., Bull, 24: 111-123.

Sloan, N.A. 1985. Distribution by depth of Lithodes aequispina and Paralithodes camtschatica confined in northern British Columbia fjords. Proc. Int. King crab symp., Jan. 1985, Anchorage, Alaska. University of Alaska Sea Grant Report, 85(12): 63-68.

Starr, R.M., D.S. Fox, M.A. Hixon, B.N. Tissot, G.E. Johnson and W.H. Barss. 1996. Comparison of submersible-survey and hydroacoustic-survey estimates of fish density on a rocky bank. US Fish. Bull., 94: 113-123.

Stein, D.L., B.N. Tisson, M.A. Hixon and W. Barss. 1992. Fish-habitat associations on a deep reef at the edge of the Oregon continental shell. Fish. Bull., 90: 540-551. 
Stevens, B.G., J.H. Bowerman, R.A. MacIntosh and J.A. Haaga. 1992. Report to industry on the 1992 Eastern Bering Sea crab survey. Alaska Fisheries Science Center Processed Report, 92(12): 57 pp.

Stevens, B.G., W.E. Donaldson, J.A. Haaga and J.E. Munk. 1993. Morphometry and maturity of paired Tanner crab, Chionoecetes bairdi (Decapoda: Majidae), from shallow-and deepwater environments. Can. J. Fish. Aquat. Sci., 50: 15041516.

Stevens, B.G., J.A. Haaga and W.E. Donaldson. 1994a. Aggregative mating of Tanner crab, Chionoecetes bairdi (Decapoda: Majidae). Can. J. Fish. Aquat. Sci., 51: 1273-1280.

Stevens, B.G., J.A. Haaga and R.A. MacIntosh. 1994b. Report to industry on the 1994 Eastern Bering Sea crab survey. Alaska Fisheries Science Center Processed Report, 94(07): 52 pp.

Stevens, B.G., J.A. Haaga and R.A. MacIntosh. 1996. Report to industry on the 1995 Eastern Bering Sea crab survey. Alaska Fisheries Science Center Processed Report, 96(01): 51 pp.

Recibido el 30 de julio de 1996.

Aceptado el 10 de noviembre de 1996.
Stone, R.P., C.E. O'Clair and T.C. Shirley. 1992. Seasonal migration and distribution of female red king crabs in a southeast Alaskan estuary. J. Crust. Biol., 12(4): 546-560.

Stone, R.P., C.E. O'Clair and T.C. Shirley. 1993. Aggregating behavior of ovigerous female red king crab, Paralithodes camtschaticus, in Auke Bay, Alaska. Can. J. Fish. Aquat. Sci., 50: 750-758.

Tyler, A.V. and G.H. Kruse. 1995. Report of the modeling workshop on year-class strength formation of red king crab. Regional Information Report, 5J95-11. Alaska Department of Fish And Game, 20 pp.

Tyler, P.A. and H. Zibrowius. 1991. Submersible observations of the invertebrate fauna on the continental slope southwest of Ireland (NE Atlantic Ocean). Oceanologica Acta, 15(2): 211-226.

Wallace, M.M., J.Pertuit and A.R. Hvatum. 1949. Contribution to the biology of the king crab (Paralithodes camtschatica Tilesius). Fishery Leaflet 340, Fish and Wildlife Service, United

Weber, D.G. 1967. Growth of the inmature king crab, Paralithodes camtschatica (Tilesus). Bull. Int. North Pac. Fish. Comm., 21: 21-53. 